\title{
Study on Mobile Learning Mode Based on WeChat Official Account in Medical Universities in Minority Areas
}

\author{
Yan Li*, Liqing Li*, Qichuan Huang, Yan-E Zhou, Qianli Tang\#, Xianjiu Liao" \\ Youjiang Medical University for Nationalities, Baise, China \\ Email: "htmgx919@163.com, "lxj2006910@163.com
}

How to cite this paper: Li, Y., Li, L. Q., Huang, Q. C., Zhou, Y.-E, Tang, Q. L., \& Liao, X. J. (2020). Study on Mobile Learning Mode Based on WeChat Official Account in Medical Universities in Minority Areas. Creative Education, 11, 1776-1782. https://doi.org/10.4236/ce.2020.119129

Received: September 1, 2020

Accepted: September 20, 2020

Published: September 23, 2020

Copyright $\odot 2020$ by author(s) and Scientific Research Publishing Inc. This work is licensed under the Creative Commons Attribution International License (CC BY 4.0).

http://creativecommons.org/licenses/by/4.0/

\begin{abstract}
In the era of Internet plus, thanks to the popularity of mobile terminals, it is quick and convenient for people to get information and knowledge. The mobile learning mode of WeChat official account assisted teaching provides students with an independent learning platform, which combines information technology and classroom teaching. As an expansion and extension of the traditional classroom, it can cultivate the independent learning ability of students and promoted students to change from "passive learning" to "active learning". Taking WeChat official account as an example, we will explore the teaching mode of "Internet plus Education" and discuss the construction of learner-centered, online and offline education ecology based on WeChat official account. In addition, we hope to provide some reference for the teaching reform of "Internet plus Education" mode in our country.
\end{abstract}

\section{Keywords}

WeChat Official Account, Mobile Learning, Duifene, Moso Tech, Medical Universities, Rain Classroom

\section{Introduction}

In the era of Internet plus, thanks to the popularity of mobile terminals, it is quick and convenient for people to get information and knowledge. As contemporary undergraduates tend to accept new things, they are interested in new technologies and new forms of learning. The mobile learning mode, which uses mobile terminals to assist teaching, is an expansion and extension of the traditional classroom, making great changes in the learning methods of students $(\mathrm{Li}$,

*These authors contributed equally to this work. 
Jin, \& Zhang, 2020). The Circular on the 13th Five-Year Plan for the Development of National Education issued by the State Council pointed out that a new breakthrough in education informatization should be achieved, a new situation of integration, innovation and development of information technology and education should be formed, and efforts should be made to build a networked, digital, personalized and lifelong education system, thus forming a learning environment, in which everyone can learn at anytime and anywhere. The Action Plan for Education Informatization 2.0 issued by the Ministry of Education states the construction of an integrated "Internet plus Education" platform, the introduction of a "platform plus education" service mode, the overall improvement of information technology literacy of teachers and student, and the exploration of a new mode of education governance in the information age.

The "Internet plus Education" Action Plan of Guangxi Province (2018-2022) mentioned that we should adhere to the core concept of in-depth integration of information technology and education, build a new educational ecology centered on learners and combining online and offline, establish and improve the sustainable development mechanism of educational informatization, and strive to build an educational informatization system that is suitable for educational modernization development goals of Guangxi. In particular, it is mentioned that the we should make full use of the supporting and leading role of information technology, realize fair and quality education, promote the all-round development of students, build the "Internet plus Education" platform, thus promoting the transformation from improving the information technology application ability of teachers and students to improving their information literacy in an all-round way. Obviously, the mode of "Internet plus Education" is not only the only way to the process of education informatization, but also the overall layout.

In recent years, with the integration and development of information technology and blended teaching, interactive teaching has been realized effectively by using WeChat (Xiang, 2020). There are already some WeChat official accounts about teaching, which can satisfy the needs of interactive teaching for teachers. Among them, WeChat official accounts such as Duifene, Moso Tech and Rain Classroom not only realize resource sharing, but also have the functions of student grouping, online question answering, online testing, sign-in, discussion, etc., which can realize interactive communication and learning between teachers and students (Zhang \& Liu, 2018). Taking WeChat official account as an example, this thesis explores the teaching mode of "Internet plus Education" and discusses the construction of learner-centered, online and offline education ecology based on WeChat official account. In addition, this thesis hopes to provide some reference for the teaching reform of "Internet plus Education" mode in our country.

\section{Mobile Learning Mode in the Era of "Internet Plus"}

As an important part of the development of educational informatization and the main trend of future teaching development, mobile learning enables learners to 
learn anytime and anywhere, which meets the need of personalized learning. Mobile Learning is a kind of learning that arises with the development of information technology, which can take place at anytime and anywhere by using mobile devices. Based on high intelligence and digitalization, mobile learning can quickly mobilize the required resources, realize the effective allocation and sharing of resources, enable students to learn at anytime and anywhere without restriction. Learners can learn independently through the Internet at anytime and anywhere by using mobile electronic devices such as smart phones, tablet computers and other mobile terminals (Ke, 2018). The main features of mobile learning are convenience and utility. It is one of the ideal paths to realize the development goal of national educational modernization that "everyone can learn at anytime and anywhere". Mobile learning can stimulate subjective initiative of learners. Compared with traditional learning, it has the advantages of high efficiency, interactivity and fragmentation, emphasizing "student-centered".

Nowadays, the rapid development and construction of universities, and the wide development and coverage of mobile network construction provide favorable conditions for mobile learning in universities. WeChat official account requires users to log in through mobile phones with the support of wireless network. In the WeChat ranking of national universities organized by China Youth Daily, the official account of Youjiang Medical University for Nationalities has been remained one of the top 100 in the country for a long time, which shows that our students are enthusiastic about using intelligent devices for communication and learning. In 2019, the WIFI in the campus of Youjiang Medical University for Nationalities has been significantly improved. At present, the total bandwidth is $40 \mathrm{Gbps}$, and students can use $2 \mathrm{~GB}$ of free Internet traffic per month, which supports mobile learning and meets the traffic required for interactive teaching using WeChat official account. Thus, teachers can share more and better online resources with students to promote interactive teaching and fundamentally improve the self-learning ability of students.

\section{Common Wechat Official Accounts about Mobile Interactive Teaching}

In the era of mobile Internet plus, teachers can use mobile Internet equipment and modern technological means APP as assistance in teaching to communicate with students in real time. There are already some WeChat official account about teaching, which can satisfy the needs of interactive teaching for teachers. Among them, Duifene, Moso Tech and Rain Classroom are the more familiar WeChat official accounts. Here we will introduce taking them as examples.

As Duifene is a teaching official account that integrates various functions, we can complete the basic setting by adding semesters, courses and classes, and students can join the class by scanning the two-dimensional code of the class. The Duifene Platform provides teaching function service modules such as students in class, curriculum resources, homework, WeChat messages, attendance, random grouping, manual grouping, forum, achievement book, online exercises, 
classroom questioning, questionnaires, voting, activities, teaching evaluation, barrage discussion, student mutual testing, etc. In addition, teachers and students can use all the functions and services of the "Duifene" Platform simultaneously on computers and mobile phones. The "Duifene" Platform, the first new teaching platform tailored for Chinese teachers, is simple and practical for teachers and students to carry out interactive communication and learning, so that information technology can truly serve teachers and students, which is suitable for various teaching modes (Sun \& Wang, 2019).

As a mobile learning platform based on Internet technology, Moso Tech can feedback the interaction inside and outside the class in real time. Moso Tech provides diversified teaching interactions for teachers and students and assists teachers to carry out various teaching activities. It consists of five modules: "Resource" module, in which teachers can upload resources; "Member" module, which provides attendance function; "Activity" module, "Message" module and "Details" module. The "Activity" module provides: assignments/group tasks, activity libraries, voting/questionnaires, brainstorming, answering questions/discussions, tests and other flexible and diverse forms of activities. The Moso Tech Platform can count the details of students' personal experience points, including: Experience points gained from activities such as non-video resource learning, video resource learning, sign-in, testing, discussion and question answering, brainstorming, voting questionnaires and homework/group tasks. Moso Tech provides students with a personalized learning platform, which can improve learning efficiency and self-confidence of students (Zhang, 2020).

Rain Classroom is a network intelligent teaching terminal that integrates WeChat and PowerPoint. It closely links students' extracurricular learning before and after class with classroom learning, which closely connects "preview before class-practice in class-feedback after class". Teachers can send preview courseware to students' mobile phone terminals in real time through WeChat, and students can feedback in time through communication with teachers; it provides functions of real-time question answering, barrage interaction, real-time evaluation and questionnaire of teaching effect, real-time collection of classroom data, which can improve the teaching efficiency in class and the self-study efficiency before and after class. In every teaching link before, during and after class, "Rain Classroom" provides teachers and students with complete and comprehensive data support, personalized reports, automatic task notification, etc., which makes teaching of teachers and learning of students clearer. At present, more and more universities have adopted "Rain Classroom" into classroom teaching (Zheng \& Li, 2020).

\section{Advantages of Mobile Learning Mode Based on WeChat Official Account}

As a medium of mobile learning mode, WeChat official account has the following advantages: 1) Convenient sign-in The sign-in function provided by WeChat official accounts such as Duifene and Moso Tech is simple and convenient, 
which saves the time used for roll call, and the overall attendance of the class can be obtained through the data analysis function provided by the official account. 2) In favor of "learning at anytime and anywhere". WeChat is a popular platform for students to carry out mobile learning on WeChat official account platform, which is convenient and novel for students with full of freshness and fashion. Students can effectively use the fragmented time to carry out ubiquitous learning at anytime and anywhere. 3) Enrich teaching resources. Teachers can push relevant teaching resources to students through WeChat official accounts such as Duifene and Moso Tech to expand the depth and breadth of teaching knowledge. 4) Excellent statistical function, which is beneficial to the implementation of formative evaluation. By using these WeChat official accounts such as Duifene and Moso Tech that have powerful statistical analysis functions, the detailed data of students' entire learning process, such as watching courseware, completing homework and classroom activities, such as attendance, tests and discussions, can be recorded. Therefore, a formative evaluation is formed, which is conducive to the implementation of formative evaluation. 5) Strengthen the communication between teachers and students, and effectively monitor the learning process. WeChat official account provides more opportunities of communication and mutual assistance for learners, which enables learners to solve their problems and difficulties more quickly through timely mutual assistance and discussion. Teachers can collect students' feedback through WeChat official account, provide individual guidance to students, collect feedback questions, purposefully fill a vacancy leak, effectively monitor students' learning process, urge students to complete learning tasks on time, and improve learning performance and results.

\section{Study on the Application of Mobile Learning Mode Based on WeChat Official Account}

1) Preview before class

Before class, the teacher will deliver PPT courseware, micro-course videos, essential posts and other learning resources to the students through WeChat official accounts such as Duifene and Moso Tech to guide them to preview. Teachers can send notices on WeChat official accounts to remind students to preview before class. In addition, teachers can see the process that students learn pre-class learning resources on WeChat official account platforms such as Duifene and Moso Tech.

2) Classroom teaching

The teaching hours of basic courses in medical universities are relatively tight. Under the traditional teaching mode, quite a number of students only passively take notes in class rather than actively thinking about the contents explained by the teacher, thus the class effect is poor. By introducing WeChat official accounts into classroom teaching, Duifene, Moso Tech, Rain Classroom and other WeChat official accounts provide teachers and students with classroom interaction 
links such as discussion, voting, question answering and asking, which enable students to express their opinions, solve the problem of low classroom speech rate in the past and enrich teaching activities. Teachers can also guide students to concentrate on the teacher's explanation of knowledge points during the course, so students can keep up with the teacher's thinking in time. For knowledge points that are not understood, students can check the teaching materials provided by WeChat official account during break instead of passively taking notes.

3) Review after class

When reviewing after class, students can communicate and learn with teachers and other students through WeChat official account at anytime and anywhere. Teachers can also issue test questions through WeChat official account to check students' learning progress. According to the students' question answering and the relevant teaching information fed back from the platform, teachers can fully understand the learning progress of the whole class and optimize the teaching methods in time. At the same time, teachers can push the learning resources for the next classroom teaching to carry out the next teaching.

\section{Conclusion}

In the era of Internet plus, the research of mobile learning mode is more and more abundant, and there is more and more software suitable for mobile learning. Taking WeChat official account as an example, we carry out a study of the application of WeChat official account mobile learning platform to teaching, which has changed the traditional teaching mode. As the learning resources are stored in WeChat official account mobile learning platform, students can use mobile devices to carry out fragmented mobile learning, and the diversified teaching interaction links can mobilize the enthusiasm of students. Although the use of WeChat official account mobile learning platform in teaching still needs further exploration, it is an inevitable requirement in the "Internet plus" era that promotes the in-depth integration of information technology and education and teaching, which requires teachers to dare to explore new ways that combine WeChat official account mobile learning platform with classroom teaching through practice, thus opening up a new situation for information education and teaching. Taking WeChat official account as an example, we hope to attract more medical educators to participate in it, jointly develop the mobile learning mode and promote the construction of the integrated "Internet plus Education".

\section{Fund Program}

The 2017 Guangxi Vocational Education Teaching Reform Research Project + "Research and Practice of Flip Classroom Based on WeChat Platform Combined with Formative Evaluation in Teaching-Taking Higher Vocational Analysis and Testing Related Courses as an Example" + (GXGZJG2017A057). 


\section{Conflicts of Interest}

The authors declare no conflicts of interest regarding the publication of this paper.

\section{References}

Ke, M. (2018). Construction of Blended Teaching Mode of Medical English Viewing, Listening and Speaking from the Perspective of Mobile Learning Theory. Course Education Research, No. 49, 99-100.

Li, X., Jin, A. A., \& Zhang, Y. Q. (2020). Learner-Driven Mobile Learning Mode Construction and WeChat Development Practice. The Chinese Journal of ICT in Education, No. 5, 77-81.

Sun, S. S., \& Wang, P. Y. (2019). Application of WeChat Duifene Teaching Platform in Epidemiology Teaching. China Higher Medical Education, No. 6, 67-68.

Xiang, Q. (2020). Study on the Application of WeChat Interactive Teaching Mode in Ophthalmology Clinical Nursing Teaching. China Health Industry, 17, 151-152.

Zhang, C., \& Liu, Z. H. (2018). Practical Research on Mobile English Learning Mode in Higher Vocational Colleges Based on WeChat Duifene Platform. Journal of Jiamusi Vocational Institute, 192, 271-272+274.

Zhang, P. (2020). Research on Flip Classroom Teaching Mode Based on Moso Tech and its Application. University Education, No. 3, 42-45.

Zheng, X., \& Li, X. P. (2020). Blended Teaching Practice and Innovation Based on WeChat "Rain Classroom”. Heilongjiang Science, 11, 36-37. 